\title{
ARSENIC STRESS TOLERANCE IN LENTIL VARIETIES
}

\author{
M. S. Islam ${ }^{1}$ and M. H. Sohag ${ }^{2}$ \\ ${ }^{1}$ Professor, Department of Agronomy, Sher-e- Bangla Agricultural University, Dhaka \\ ${ }^{2}$ M.S. student, Department of Agronomy, Sher-e- Bangla Agricultural University, Dhaka \\ Corresponding author: msislamsau@yahoo.com
}

(Received: 31 July 2021, Accepted: 16 September 2021)

Keywords: Soil arsenic, plant performance, seed arsenic, seed yield, lentil

\begin{abstract}
A pot experiment was conducted inside a rain- shelter in the Department of Agronomy, Sher-e-Bangla Agricultural University, Dhaka in 2016 to evaluate the arsenic (As) stress tolerance of seven lentil varieties, viz., BARIMasur-1, BARIMasur-2, BARIMasur-3, BARIMasur-4, BARIMasur-5, BARIMasur-6 and BARIMasur-7 against three levels of arsenic stress viz., no arsenic stress (control), $25 \mathrm{mg}$ As / $\mathrm{kg}$ soil and $50 \mathrm{mg}$ As / kg soil. Arsenic treatment was imposed during pot filling with $10 \mathrm{~kg}$ air- dried soil pot ${ }^{-1}$. The pots were fertilized with $0.225 \mathrm{~g}$ urea, $0.425 \mathrm{~g}$ TSP and $0.175 \mathrm{~g} \mathrm{MoP} \mathrm{pot}^{-1}$ before seed sowing. Six healthy seeds of seven lentil varieties were sown in each pot and the plants were thinned to four after three weeks later. It was observed that increasing levels of As significantly decreased pods plant ${ }^{-1}, 1000$ seeds weight, seed yield, stover yield, harvest index and relative values of these parameters, whereas increased seed arsenic content and relative seed arsenic content in all the lentil varieties studied. Although BARIMasur-7, BARIMasur-6 and BARIMasur-5 gave the higher seed yield, their relative seed yield, relative values of yield components, relative stover yield and relative harvest index were lower, but seed arsenic content and relative seed arsenic content were higher compared to that of BARIMasur-1, BARIMasur-2, BARIMasur-3 and BARIMasur-4. Therefore, BARIMasur-1, BARIMasur-2, BARIMasur-3 and BARIMasur-4 varieties were superior and safe for consumption considering seed arsenic content and suitable for breeding considering relative seed arsenic content under soil arsenic stress conditions. Correlation studies indicated that As stress decreased relative seed yield by most negatively influencing the relative 1000 -seeds weight followed by relative pods plant ${ }^{-1}$, relative stover yield and relative seeds pod ${ }^{-1}$.
\end{abstract}

\section{Introduction}

Environmental pollution in Bangladesh has been becoming worse day by day. The arsenic (As) contamination of groundwater has now become a serious threat to public health in Bangladesh, as over $97 \%$ of its population is dependent upon groundwater for drinking purposes (Ahmed, 2002, Shankar and Shanker, 2014). The most of districts in Bangladesh is highly polluted with arsenic. The presence of high arsenic content in the soil has led to its accumulation in paddy, which has resulted in its collection at the concentration beyond the food safety threshold (Zhu et al., 2008; Zheng et al., 2011).

Lentil (Lens culinaris L.) is one of the major pulse crops of the world. It is a principal source of protein in the human diet. In Bangladesh, it ranks first among the pulse crops in terms of area and production (BBS, 2019). The national average yield and total production in Bangladesh are $1230.92 \mathrm{~kg} / \mathrm{ha}$ and 175384 tons, respectively. The total production is increasing day by day as such consumption also rapidly increasing in Bangladesh (BBS, 2019). Lentil is mainly cultivated in greater Faridpur, Jessore, Kushtia, Pabna, Laksmipur, Rajshahi where the soils and groundwater are contaminated with As (Afzal et al., 1999; BAMWSP, 2005; APSU, 2004). People of that As affected areas as well as of the whole country are at risk of consuming As- contaminated lentil and creating a serious problem for human 
health. Several reviews have been examined the sources and behavior of As in different plants, but speciation and toxicity in lentil and its impact on sustainable agriculture are not established. Under this circumstance, this experiment was initiated to examine the arsenic stress tolerance of seven lentil varieties.

\section{Materials and Methods}

A pot experiment was carried out at Sher-e-Bangla Agricultural University in the rabi season of 20162017 to screen out seven lentil varieties against arsenic stress. The treatments consisted of the seven BARI released lentil varieties (viz., BARI Masur 1, BARI Masur 2, BARI Masur 3, BARI Masur 4, BARI Masur 5, BARI Masur 6, and BARI Masur 7) and three arsenic treatments (Control i.e., no arsenic, $25 \mathrm{mg} \mathrm{As} / \mathrm{kg}$ soil, and $50 \mathrm{mg}$ As $/ \mathrm{kg}$ soil). The experiment was laid out in a randomized complete block design with 5 replications. Fresh and healthy seeds of seven varieties of lentil were washed thrice in sterile distilled water and six seeds were sown in each earthen pot of equal sizes (30 $\mathrm{cm}$ in height and $40 \mathrm{~cm}$ in diameter). The soil was mixed, air-dried, and ground to a particle size of $<2$ $\mathrm{mm}$. Ten $\mathrm{kg}$ of air-dried soil was put in each pot. Seeds were sown in a clean soil (control) and a soil

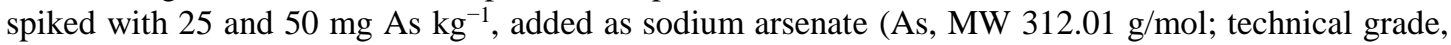
purity $98.5 \%$, Sigma-Aldrich, Bangalore, India). Before sowing seeds, the pots were fertilized with $0.225 \mathrm{~g}$ urea, $0.425 \mathrm{~g}$ TSP and $0.175 \mathrm{~g} \mathrm{MoP} \mathrm{pot}^{-1}$, which resembled to 45,85 and $35 \mathrm{~kg} \mathrm{ha}^{-1}$ of urea, TSP and MoP, respectively (AIS, 2015). The pots were arranged in a completely randomized design, and the plants were grown in a net house covered with polythene sheets at the middle stage of vegetative growth. The plants were thinned to 4 per pot three weeks later. Data were recorded on plant height, pods plant ${ }^{-1}$, seeds pod ${ }^{-1}, 1000$ - seed weight, stover yield plant ${ }^{-1}$, seed yield plant ${ }^{-1}$ and harvest index. Relative values of all the plant characters studied and seed arsenic content was calculated as, relative value $=$ value under As stress $\div$ value under control condition. Based on the relative values of all the plant characters studied and seed arsenic content, the lentil varieties tolerant and susceptible to As stress were selected. Data were analysed and the means were compared by the least significance difference (LSD) test.

\section{Results and Discussion}

The effects of different levels of arsenic (As) on different yield attributes, yields and seed As content of seven lentil cultivars have been presented and discussed below:

\section{Effects of arsenic on the production of pods and seeds of lentil}

Arsenic (As) stress significantly reduced number of pods plant ${ }^{-1}$ in all the lentil varieties studied except BRIMasur-1 and BARIMasur-2 (Table 1). The highest number of pods plant ${ }^{-1}$ was found in all the varieties with no As treatment and it was significantly decreased with the increasing level of As in all the varieties. The significantly lowest number of pods plant ${ }^{-1}$ was found in $\mathrm{As}_{50}$ (50 mg As kg-1 soil) in all the 5 varieties (BRIMasur-3, BARIMasur-4, BARIMasur-5, BARIMasur-6 and BARIasur-7) which was statistically identical to that of all the varieties except BARIMasur-6. The reduction in number of pods plant ${ }^{-1}$ might be due to the reduction in translocation of photosynthates towards reproductive organs specially flower buds as a result of oxidative stress created by As stress. The negative effect on photosynthesis and also on increasing oxidative stress in rice due to arsenic stress was also reported by Gautam et al. (2019) and Gautam et al. (2020). The reduction in pods plant ${ }^{-1}$ was also reported by Bustingorri and Lavado (2014) in soybean.

The number of seeds pod ${ }^{-1}$ was not significantly influenced by stress (Table 1). The increasing level of as reduced number of seeds pod $^{-1}$ in all the seven lentil varieties studied but reduction was statistically insignificant. The variable effect of As on number of seeds pod $^{-1}$ or number of seeds per panicle were found by different researchers in different crops. 
Table 1. Pod and seed production of seven lentil varieties as influenced by arsenic level

\begin{tabular}{|c|c|c|c|c|c|c|c|c|c|c|c|c|c|c|}
\hline \multirow{2}{*}{$\begin{array}{l}\text { Arsenic } \\
\text { level }\end{array}$} & \multicolumn{7}{|c|}{ Pods plant $^{-1}$ (no.) } & \multicolumn{7}{|c|}{ Seeds pod $^{-1}$ (no.) } \\
\hline & $\mathbf{V}_{1}$ & $\mathbf{V}_{2}$ & $\mathbf{V}_{3}$ & $\mathbf{V}_{4}$ & $V_{5}$ & $V_{6}$ & $V_{7}$ & $\mathbf{V}_{1}$ & $\mathbf{V}_{2}$ & $\mathbf{V}_{3}$ & $\mathbf{V}_{4}$ & $V_{5}$ & $V_{6}$ & $\mathbf{V}_{7}$ \\
\hline $\mathrm{As}_{0}$ & 25.9 & 21.5 & 37.1 & 37.7 & 38.1 & 45.3 & 56.9 & 1.18 & 1.21 & 1.27 & 1.33 & 1.42 & 1.57 & 1.64 \\
\hline $\mathrm{As}_{25}$ & $\begin{array}{c}24.8 \\
(0.956)\end{array}$ & $\begin{array}{c}20.6 \\
(0.958)\end{array}$ & $\begin{array}{c}35.0 \\
(0.943)\end{array}$ & $\begin{array}{c}35.8 \\
(0.950)\end{array}$ & $\begin{array}{c}33.7 \\
(0.885)\end{array}$ & $\begin{array}{c}42.0 \\
(0.927)\end{array}$ & $\begin{array}{c}39.9 \\
(0.701)\end{array}$ & $\begin{array}{c}1.13 \\
(0.958)\end{array}$ & $\begin{array}{c}1.16 \\
(0.959)\end{array}$ & $\begin{array}{c}1.20 \\
(0.945)\end{array}$ & $\begin{array}{c}1.26 \\
(0.947)\end{array}$ & $\begin{array}{c}1.26 \\
(0.947)\end{array}$ & $\begin{array}{c}1.46 \\
(0.930)\end{array}$ & $\begin{array}{c}1.27 \\
(0.774)\end{array}$ \\
\hline $\mathrm{As}_{50}$ & $\begin{array}{c}23.9 \\
(0.923)\end{array}$ & $\begin{array}{c}19.5 \\
(0.907)\end{array}$ & $\begin{array}{c}33.7 \\
(0.908)\end{array}$ & $\begin{array}{c}34.3 \\
(0.910)\end{array}$ & $\begin{array}{c}31.9 \\
(0.837)\end{array}$ & $\begin{array}{c}37.8 \\
(0.834)\end{array}$ & $\begin{array}{c}38.1 \\
(0.670)\end{array}$ & $\begin{array}{c}1.09 \\
(0.924)\end{array}$ & $\begin{array}{c}1.10 \\
(0.909)\end{array}$ & $\begin{array}{c}1.16 \\
(0.913)\end{array}$ & $\begin{array}{c}1.21 \\
(0.910)\end{array}$ & $\begin{array}{c}1.19 \\
(0.838)\end{array}$ & $\begin{array}{c}1.31 \\
(0.834)\end{array}$ & $\begin{array}{c}1.07 \\
(0.652)\end{array}$ \\
\hline $\operatorname{LSD}_{(0.05)}$ & & & & 3.26 & & & & & & & 0.92 & & & \\
\hline CV (\%) & & & & 4.8 & & & & & & & 5.6 & & & \\
\hline
\end{tabular}

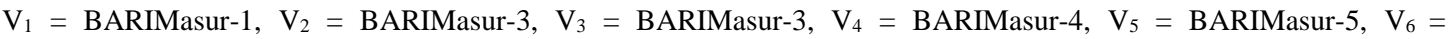
BARIMasur-6, $\mathrm{V}_{7}=$ BARIMasur-7;

As $0=$ No arsenic, As $25=25 \mathrm{mg}$ arsenic kg ${ }^{-1}$ soil, As50 $=50 \mathrm{mg}$ arsenic kg ${ }^{-1}$ soil

Figures in the parentheses indicate relative values

\section{Effects of arsenic on the seed size and stover yield of lentil}

Different As levels had significant influence on 1000- seeds weight of lentil varieties. In all the seven lentil varieties, As level decreased 1000- seeds weight (Table 2) with the increasing level of As. The decrease in 1000 -seeds weight in BARIMasur-1, BARIMasur-2, BARIMasur-3 and BARIMasur-4 due to As level was insignificant whereas, it was significantly increasd in BARMasur- 5, BARIMasur-6 and BARIMasur-7. The highest 1000seeds weight in BARIMasur-5 (18.3 g), BARIMasur-6 (19.5 g) and BARIMasur-7 (20.6 g) were found in no arsenic $\left(\mathrm{As}_{0}\right)$ treatment and the significantly lowest in $\mathrm{As}_{50}$ treatment. The lowest values for this parameter were $15.3 \mathrm{~g}$ for BARIMasur-5, $16.2 \mathrm{~g}$ for BARIMasur-6, and $13.5 \mathrm{~g}$ for BARIMasur-7. The treatment consisting $25 \mathrm{mg}$ arsenic $\mathrm{kg}^{-1}$ soil ( $\mathrm{As}_{25}$ ) produced lower 1000- seeds weight and was statistically identical to that of both $\mathrm{As}_{0}$ and $\mathrm{As}_{50}$ in all the seven lentil varieties except BARIMasur-7. Reduction in 1000 -seeds weight might be due to hamper lipid peroxidation, ion leakage, oxidative stress and photosynthesis. These results may also be supported by the findings of Lersen et al. (1992) and Ahmed (2002).

\section{Stover yield}

Stover yield of seven lentil varieties was significantly influenced by different levels of As (Table 2). Arsenic level decreased stover yield, seed yield, relative seed yield and harvest index of seven rice varieties with increasing level of As. The highest stover yield plant ${ }^{-1}$ and seed yield plant $^{-1}$ in BARIMasur-1 (2.31 g), BARIMasur-2 (2.44 g), BARIMasur-3 (2.57 g), BARIMasur-4 (2.61 g), BARIMasur-5 (2.76 g), BARIMasur-6 (3.27 g) and BARIMasur-7 (4.05 g) were found in no arsenic $\left(\mathrm{As}_{0}\right)$ treatment and the lowest in As $5_{50}$ treatment which were statistically identical to that of $\mathrm{As}_{25}$ treatment. The treatment consisting $25 \mathrm{mg}$ arsenic $\mathrm{kg}^{-1}$ soil $\left(\mathrm{As}_{25}\right)$ produced the intermediate but statistically identical values for stover yield to that of $\mathrm{As}_{0}$ (No arsenic) and $\mathrm{As}_{50}$ (50 mg As kg-1 soil) treatment. The decrease in stover yield might be due to the decrease in photosynthesis as well as dry matter production caused by arsenic stress as reported by Srivastava and Sharma (2013) in blackgram, Hi- Bo et al. (2013) in soybean.

\section{Effects of arsenic on seed yield of lentil}

Seed yield of seven lentil varieties was significantly influenced by different levels of As (Table 3). Arsenic level decreased seed yield of seven lentil varieties with increasing level of As. The highest seed yield plant ${ }^{-1}$ in BARIMasur-1 (2.11 g), BARIMasur-2 (2.22 g), BARIMasur-3 (2.34 g), BARIMasur-4 (2.37 g), BARIMasur-5 (2.43 g), BARIMasur-6 (2.89 g) and BARIMasur-7 (3.15 g) were found in no arsenic $\left(\mathrm{As}_{0}\right)$ treatment and the lowest in $\mathrm{As}_{50}$ treatment and that were statistically identical to that of $\mathrm{As}_{25}$ treatment. The treatment consisting $25 \mathrm{mg}$ arsenic $\mathrm{kg}^{-1}$ soil $\left(\mathrm{As}_{25}\right)$ produced the 
intermediate but statistically identical values for seed yield plant ${ }^{-1}$ to that of $\mathrm{As}_{0}$ (No arsenic) and $\mathrm{As}_{50}$ (50 mg As kg-1 soil) treatment.

Table 2. Weight of 1000- seeds and stover yield of lentil varieties as influenced by arsenic levels

\begin{tabular}{|c|c|c|c|c|c|c|c|c|c|c|c|c|c|c|}
\hline \multirow{2}{*}{$\begin{array}{l}\text { Arsenic } \\
\text { level }\end{array}$} & \multicolumn{7}{|c|}{ Weight of 1000 - seeds $(\mathrm{g})$} & \multicolumn{7}{|c|}{ Stover yield $\left(\right.$ g plant $\left.^{-1}\right)$} \\
\hline & $\mathrm{V}_{1}$ & $\mathbf{V}_{2}$ & $\mathbf{V}_{\mathbf{3}}$ & $\mathrm{V}_{4}$ & $V_{5}$ & $\mathbf{V}_{6}$ & $\mathrm{~V}_{7}$ & $\mathbf{V}_{1}$ & $\mathbf{V}_{2}$ & $V_{3}$ & $\mathrm{~V}_{4}$ & $V_{5}$ & $\mathbf{V}_{6}$ & $\mathbf{V}_{7}$ \\
\hline $\mathrm{As}_{0}$ & 14.5 & 11.7 & 22.3 & 18.5 & 18.3 & 19.5 & 20.6 & 2.31 & 2.44 & 2.57 & 2.61 & 2.76 & 3.27 & 4.05 \\
\hline $\mathrm{As}_{25}$ & $\begin{array}{c}13.8 \\
(0.952)\end{array}$ & $\begin{array}{c}11.2 \\
(0.957)\end{array}$ & $\begin{array}{c}21.1 \\
(0.946)\end{array}$ & $\begin{array}{c}17.5 \\
(0.946)\end{array}$ & $\begin{array}{c}16.2 \\
(0.885)\end{array}$ & $\begin{array}{c}17.4 \\
(0.892)\end{array}$ & $\begin{array}{c}16.4 \\
(0.796)\end{array}$ & $\begin{array}{c}2.20 \\
(0.952)\end{array}$ & $\begin{array}{c}2.32 \\
(0.951)\end{array}$ & $\begin{array}{c}2.42 \\
(0.942)\end{array}$ & $\begin{array}{c}2.48 \\
(0.950)\end{array}$ & $\begin{array}{c}2.44 \\
(0.884)\end{array}$ & $\begin{array}{c}3.02 \\
(0.924)\end{array}$ & $\begin{array}{c}2.84 \\
(0.701)\end{array}$ \\
\hline $\mathrm{As}_{50}$ & $\begin{array}{c}13.4 \\
(0.924) \\
\end{array}$ & $\begin{array}{r}10.6 \\
(0.906) \\
\end{array}$ & $\begin{array}{r}20.3 \\
(0.910) \\
\end{array}$ & $\begin{array}{r}16.9 \\
(0.914) \\
\end{array}$ & $\begin{array}{r}15.3 \\
(0.836) \\
\end{array}$ & $\begin{array}{r}16.2 \\
(0.831) \\
\end{array}$ & $\begin{array}{r}13.5 \\
(0.655) \\
\end{array}$ & $\begin{array}{c}2.12 \\
(0.918) \\
\end{array}$ & $\begin{array}{c}2.21 \\
(0.906) \\
\end{array}$ & $\begin{array}{c}2.33 \\
(0.907) \\
\end{array}$ & $\begin{array}{r}2.38 \\
(0.912) \\
\end{array}$ & $\begin{array}{c}2.31 \\
(0.837) \\
\end{array}$ & $\begin{array}{c}2.73 \\
(0.834) \\
\end{array}$ & $\begin{array}{c}2.72 \\
(0.672) \\
\end{array}$ \\
\hline $\mathrm{LSD}_{(0.05)}$ & & & & 2.56 & & & & & & & 0.16 & & & \\
\hline $\mathrm{CV}(\%)$ & & & & 4.8 & & & & & & & 5.4 & & & \\
\hline
\end{tabular}

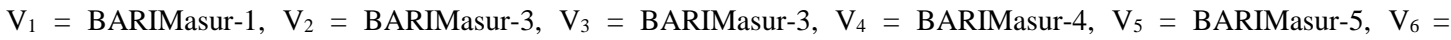
BARIMasur-6, $\mathrm{V}_{7}=$ BARIMasur-7;

As $0=$ No arsenic, As $25=25 \mathrm{mg}$ arsenic kg ${ }^{-1}$ soil, As50 $=50 \mathrm{mg}$ arsenic kg ${ }^{-1}$ soil

Figures in the parentheses indicate relative values

\section{Effects of arsenic on the harvest index of lentil}

Significant differences in harvest index due to arsenic level were found only in BARIMasur-6 and BARIMasur-7, whereas in all other lentil varieties differences were statistically similar (Table 3). Increasing arsenic level decreased harvest index in BARIMasur-6 at $\mathrm{As}_{25}$ and in BARIMasur-7 at As 50 , whereas increased in BARIMasur-7 at $\mathrm{As}_{25}$ (Table 3). These findings are also inconformity with that of Rahman et al. (2012) and Smith et al. (2003).

Table 3. Seed yield and harvest index of lentil varieties as influenced by arsenic level

\begin{tabular}{|c|c|c|c|c|c|c|c|c|c|c|c|c|c|c|}
\hline \multirow{2}{*}{$\begin{array}{l}\text { Arsenic } \\
\text { level }\end{array}$} & \multicolumn{7}{|c|}{ Seed yield (g plant ${ }^{-1}$ ) } & \multicolumn{7}{|c|}{ Harvest index (\%) } \\
\hline & $\mathbf{V}_{1}$ & $\mathbf{V}_{2}$ & $\mathbf{V}_{3}$ & $\mathrm{~V}_{4}$ & $V_{5}$ & $V_{6}$ & $\mathbf{V}_{7}$ & $\mathbf{V}_{1}$ & $\mathbf{V}_{2}$ & $V_{3}$ & $\mathbf{V}_{4}$ & $V_{5}$ & $V_{6}$ & $\mathbf{V}_{7}$ \\
\hline $\mathrm{As}_{0}$ & 2.11 & 2.22 & 2.34 & 2.37 & 2.43 & 2.89 & 3.15 & 47.74 & 47.64 & 47.66 & 47.59 & 46.82 & 46.92 & 43.75 \\
\hline $\mathrm{As}_{25}$ & $\begin{array}{c}2.02 \\
(0.96) \\
\end{array}$ & $\begin{array}{c}2.12 \\
(0.96) \\
\end{array}$ & $\begin{array}{c}2.21 \\
(0.94) \\
\end{array}$ & $\begin{array}{c}2.25 \\
(0.94) \\
\end{array}$ & $\begin{array}{c}2.15 \\
(0.88) \\
\end{array}$ & $\begin{array}{c}2.58 \\
(0.89) \\
\end{array}$ & $\begin{array}{c}2.51 \\
(0.80) \\
\end{array}$ & $\begin{array}{c}47.87 \\
(1.003)\end{array}$ & $\begin{array}{c}47.75 \\
(1.002)\end{array}$ & $\begin{array}{c}47.73 \\
(1.001) \\
\end{array}$ & $\begin{array}{c}47.57 \\
(1.000)\end{array}$ & $\begin{array}{c}46.84 \\
(1.000)\end{array}$ & $\begin{array}{c}46.07 \\
(0.982) \\
\end{array}$ & $\begin{array}{c}46.92 \\
(1.072) \\
\end{array}$ \\
\hline $\mathrm{As}_{50}$ & $\begin{array}{c}1.95 \\
(0.92) \\
\end{array}$ & $\begin{array}{c}2.01 \\
(0.91) \\
\end{array}$ & $\begin{array}{c}2.13 \\
(0.91) \\
\end{array}$ & $\begin{array}{c}2.16 \\
(0.91) \\
\end{array}$ & $\begin{array}{c}2.03 \\
(0.83) \\
\end{array}$ & $\begin{array}{c}2.41 \\
(0.83) \\
\end{array}$ & $\begin{array}{c}2.06 \\
(0.65) \\
\end{array}$ & $\begin{array}{c}47.91 \\
(1.003) \\
\end{array}$ & $\begin{array}{c}47.63 \\
(0.998) \\
\end{array}$ & $\begin{array}{c}47.76 \\
(1.002) \\
\end{array}$ & $\begin{array}{c}47.58 \\
(1.000) \\
\end{array}$ & $\begin{array}{c}46.77 \\
(0.999) \\
\end{array}$ & $\begin{array}{c}46.89 \\
(0.999) \\
\end{array}$ & $\begin{array}{c}43.1 \\
(0.985) \\
\end{array}$ \\
\hline $\operatorname{LSD}_{(0.05)}$ & & & & 0.13 & & & & & & & 3.06 & & & \\
\hline $\mathrm{CV}(\%)$ & & & & 6.1 & & & & & & & 5.8 & & & \\
\hline
\end{tabular}

$\mathrm{V}_{1}=$ BARIOMasur-1, $\mathrm{V}_{2}=$ BARMasur-3, $\mathrm{V}_{3}=$ BARIMasur-3, $\mathrm{V}_{4}=$ BARIMasur-4, $\mathrm{V}_{5}=$ BARIMasur-5, $\mathrm{V}_{6}=$ BARIMasur-6, $\mathrm{V}_{7}=$ BARIMasur-7;

As $0=$ No arsenic, As $_{25}=25 \mathrm{mg}$ arsenic kg-1 soil, As $50=50 \mathrm{mg}$ arsenic $\mathrm{kg}^{-1}$ soil

Figures in the parentheses indicate relative values

\section{Effects of arsenic on the seed arsenic content of lentil}

Seed arsenic content was significantly influenced by As level. Increase in arsenic level increased seed arsenic content (Figure 1). Seed arsenic content was significantly highest in BARIMasur-7, which was statistically identical to that of BARIMasur-6, whereas, it was significantly the lowest in BARIMasur3 , which was statistically followed by that of BARIMasur-4, BARIMasur-1 and BARasur-2 both under $\mathrm{As}_{25}$ and $\mathrm{As}_{50}$ arsenic level. This findings were informity with that of Alam et al. (2019) in other three varieties of lentil. 


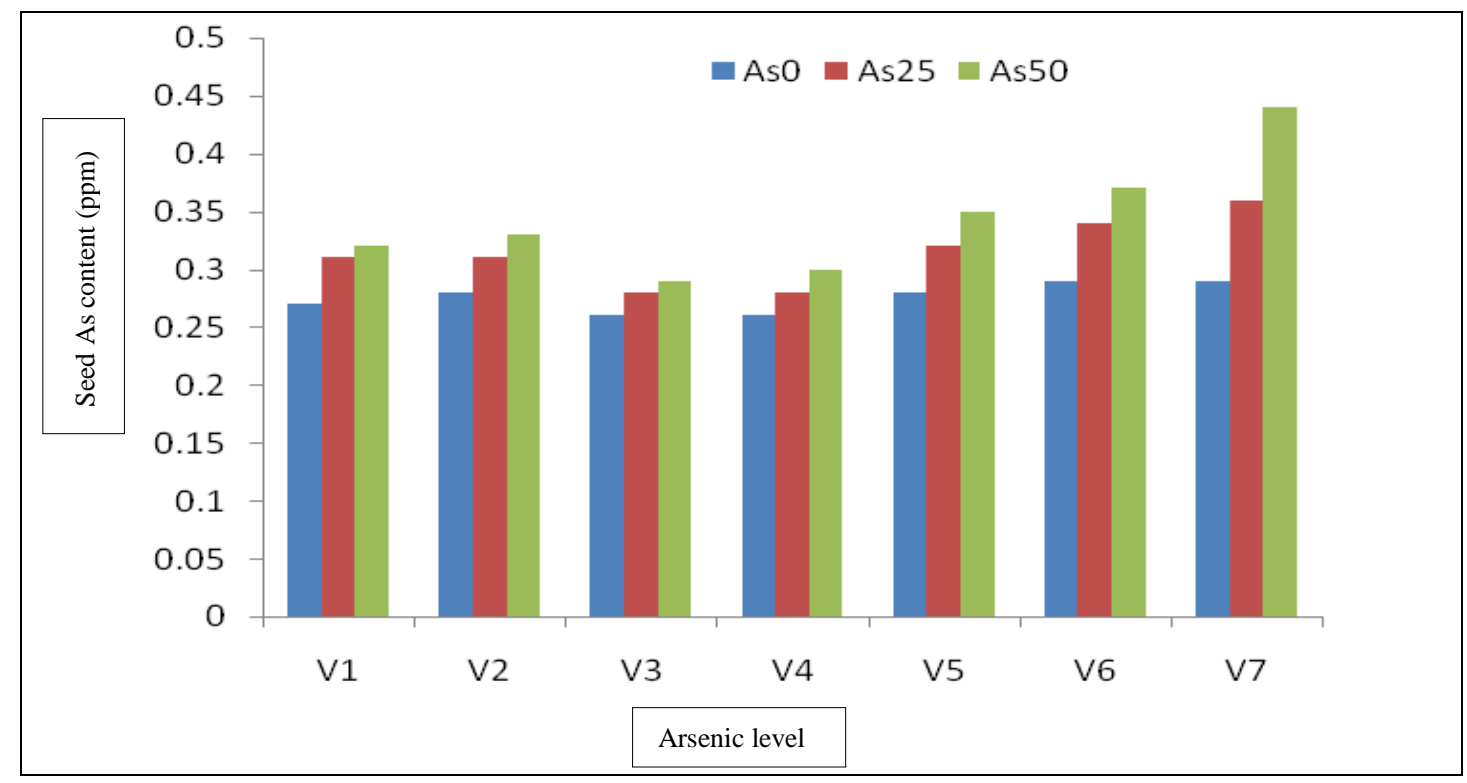

$\mathrm{V}_{1}=$ BARIMasur-1, $\mathrm{V}_{2}=$ BARIMasur- $3, \mathrm{~V}_{3}=$ BARIMasur-3, $\mathrm{V}_{4}=$ BARIMasur-4,

$\mathrm{V}_{5}=$ BARIMasur-5, $\mathrm{V}_{6}=$ BARIMasur- $6, \mathrm{~V}_{7}=$ BARIMasur -7

Fig. 1. Effect of arsenic level on As content in seed of seven lentil varieties $\left(\operatorname{LSD}_{0.05}=3.56\right)$.

\section{Effects of arsenic on the relative performance of lentil varieties}

Increase in As level decreased relative values of all the parameters studied including relative seed yield and relative seed arsenic content (Table 1, 2 \& 3 ; Figure 2). All the As level treatment significantly decreased relative seed yield in all the lentil varieties studied except BARIMasur-1 at As level $\mathrm{As}_{25}$. Relative seed yield was significantly lowest in BARIMasur- 7 which was statistically identical to that of BARIMasur-5 and BARIMasur- 6, whereas it was significantly the highest in BARIMasur-1, which was statistically identical to that of BARMasur-2, BARIMasur-3 and BARIMasur- 4 both under As 25 and $\mathrm{As}_{50}$ arsenic level. Relative seed As content was significantly highest in BARIMasur- 7, which was statistically identical to that of BARIMasur- 6 , whereas, it was significantly the lowest in BARIMasur3 , which was statistically followed by that of BARIMasur- 4, BARIMasur- 1 and BARIMasur- 2 both under $\mathrm{As}_{25}$ and $\mathrm{As}_{50}$ arsenic level. These findings are also inconformity with that of Rahman et al. (2012), Smith et al. (2003) and Alam et al. (2019). 


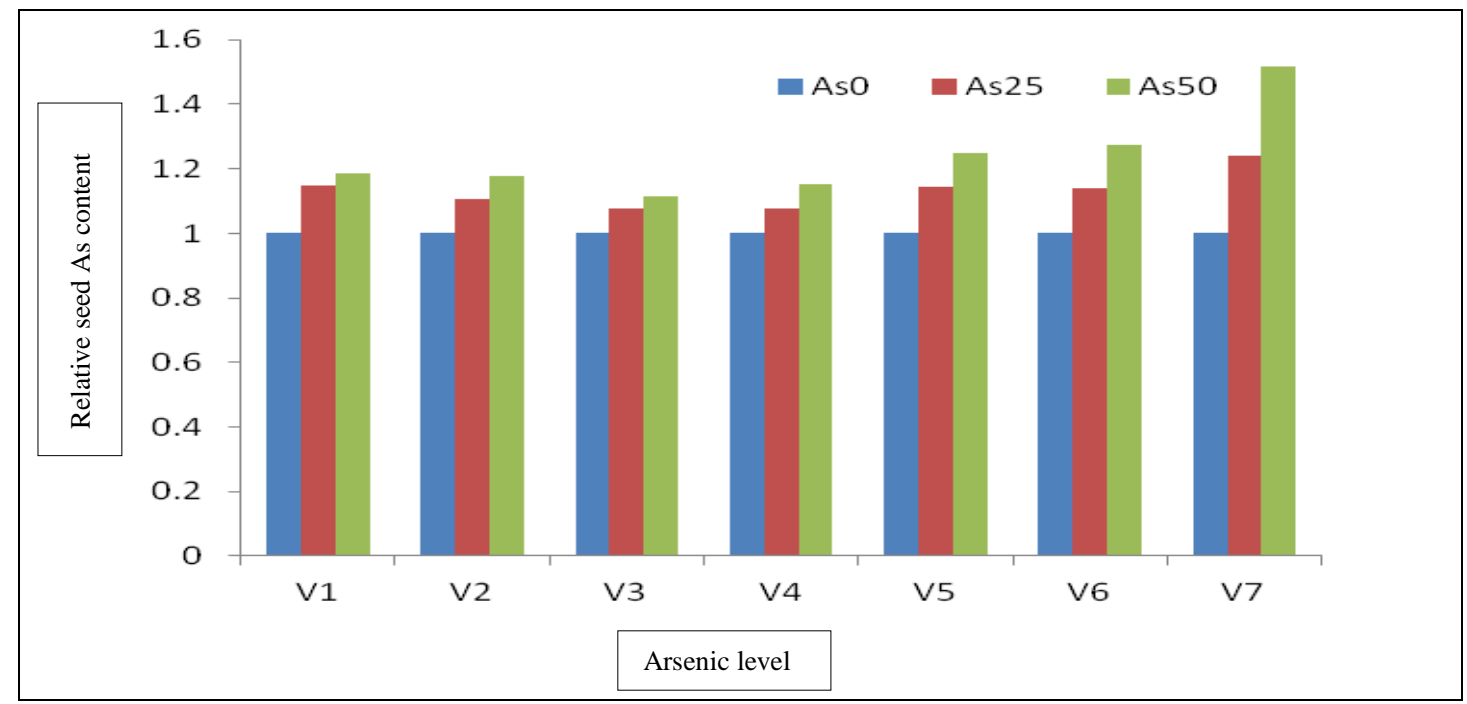

$\mathrm{V}_{1}=$ BARIMasur-1, $\mathrm{V}_{2}=$ BARIMasur-3, $\mathrm{V}_{3}=$ BARIMasur-3, $\mathrm{V}_{4}=$ BARIMasur-4, $\mathrm{V}_{5}=$ BARIMasur-5, $\mathrm{V}_{6}=$ BARIMasur- $6, \mathrm{~V}_{7}=$ BARIMasur -7

Fig. 2. Effect of arsenic level on relative As content in seed of seven lentil varieties $\left(\mathrm{LSD}_{0.05}=0.67\right)$.

Table 4. Functional relationship between relative seed yield and other relative plant characters as affected by arsenic

\begin{tabular}{llc}
\hline Plant characters & \multicolumn{2}{c}{ Regression equation and correlation coefficient $(\mathbf{r})$} \\
\hline Relative pods plant $^{-1}$ & $\mathrm{y}=0.669 \mathrm{x}+0.289$ & $\mathrm{r}=0.94^{* *}$ \\
Relative seeds pod ${ }^{-1}$ & $\mathrm{y}=0.687 \mathrm{x}+0.280$ & $\mathrm{r}=0.93^{* *}$ \\
Relative 1000 seeds weight $^{*}$ & $\mathrm{y}=0.667 \mathrm{x}+0.297$ & $\mathrm{r}=0.94^{* *}$ \\
Relative stover yield & $\mathrm{y}=0.560 \mathrm{x}+0.306$ & $\mathrm{r}=0.93^{* *}$ \\
\hline
\end{tabular}

**. Correlation is significant at the 0.01 level (2-tailed)

\section{Functional relationship between relative seed yield and relative yield components}

The significant positive correlations were found i) between relative pods plant ${ }^{-1}$ and relative seed yield $\left(\mathrm{r}=0.94^{* *}\right)$, ii) between relative seeds $\operatorname{pod}^{-1}$ and relative seed yield $\left(\mathrm{r}=0.93^{* *}\right)$, iii) between relative 1000 seeds weight and relative seed yield $\left(r=0.94^{* *}\right)$ and iv) between relative stover yield and relative seed yield $\left(r=0.93^{* *}\right)$ under As stress condition (Table 4). The functional relationships of relative seed yield with relative values of various yield components and stover yield studied indicated that the relative seed yield was most post positively correlated with the relative 1000- seeds weight followed by relative pods plant ${ }^{-1}$, relative stover yield and relative seeds pod $^{-1}$. These results again indicated that As stress decreased relative seed yield by most negatively influencing the relative 1000- seeds weight followed by relative pods plant ${ }^{-1}$, relative stover and yield relative seeds pod $^{-1}$.

\section{Conclusion}

BARIMasur-1, BARIMasur- 2, BARIMasur- 3 and BARIMasur- 4 varieties were superior and safe for consumption considering seed arsenic content and suitable for breeding considering relative seed arsenic content under soil arsenic stress conditions.

\section{References}


Afzal, M.A., M.A. Bakar and L.R. Rahman. 1999. Lentil Cultivation in Bangladesh. Lentil Blackgram Mungbean Development Pilot Project. Pub. No. 18. Bangladesh Agricultural Research Institute, Gazipur, Bangladesh.

Ahmed, M.F. 2002. Alternative water supply option for arsenic affected area of Bangladesh. International workshop on arsenic mitigation in Bangladesh, Dhaka.

AIS (Agriculture Information Service). 2015. Masur (In Bengali). Agriculture Information Service. Ministry of Agriculture, Govt. of People's Republic of Bangladesh. Dhaka, Bangladesh. http://www.ais.gov.bd/site/ekrishi/96a49836-0765-4319-9c41.

Alam, M.Z., M.A. Hoque, G.J. Ahammed, R. McGree and L.C. Boggs. 2019. Arsenic accumulation in lentil (Lens culinaris) genotypes and risk associated with consumption of grains. Scientific Reports. 9: 9431- 9439. https://doi.org/10.1038/s41598-019-45855-z

APSU (Arsenic Policy Support Unit). 2004. Risk assessment of arsenic mitigation options, phase-I (RAMMO-I). Dhaka: Arsenic Mitigation Policy Support Unit and ITB-Bangladesh Centre for Water Supply and Waste Management.

BAMWSP (Bangladesh Arsenic Mitigation Water Supply Project). 2005. Bangladesh Arsenic Water Supply Project Web site: www.bamwsp.org.

BBS (Bangladesh Bureau of Statistics). 2019. Year Book of Agricultural Statistics. Bangladesh Bureau of Statistics. Statistics Division, Ministry of Planning, Govt. of People's Republic of Bangladesh. Dhaka, Bangladesh.

Begum, M., J. Akter, M. Jahiruddin and M.R. Islam. 2008. Effect of arsenic and its interaction with phosphorus on yield and arsenic accumulation in rice. J. Bangladesh Agril. Univ. 6(2): 277-284. Bustingorri, C. and R. S. Lavado. 2014. Soybean as affected by high concentrations of arsenic and fluoride in irrigation water in controlled conditions. Agril. Water Management, 144: 134- 139. doi.org/10.1016/j.agwat.2014.06.004.

Choudhury, B., S. Chowdhury and A.K. Biswas. 2011. Regulation of growth and metabolism in rice (Oryza sativa L.) by arsenic and its possible reversal by phosphate. J. Plant Interact. 6: 15-24. doi: 10.1080/17429140903487552

Gautam, A., A.K. Pandey and R. Dubey. 2019. Effect of arsenic toxicity on photosynthesis, oxidative stress and alleviation of toxicity with herbal extracts in growing rice seedlings. Indian J. Agric. Biochem. 32: 143-148.

Gautam, A., A.K. Pandey and R.S. Dubey. 2020. Azadirachta indica and Ocimum sanctum leaf extracts alleviate arsenic toxicity by reducing arsenic uptake and improving antioxidant system in rice seedlings. Physiol. Mol. Biol. Plants. 26: 63-81. doi: 10.1007/s12298-019-00730-z.

Hi- Bo, L., Y. Lan- Fang and L. Ya- Dong. 2013. Effects of soil arsenic on soybean main traits and chlorophyll content at different growing stage. Acta Agron. Sin. 39(7): 1303- 1308. doi.org/10.3724/SP.J.1006.2013.01303.

Jha, A. and R. Dubey. 2004. Carbohydrate metabolism in growing rice seedlings under arsenic toxicity. J. Plant Physiol. 161: 867-872. doi: 10.1016/j.jplph.2004.01.004.

Jha, A. and R. Dubey. 2005. Effect of arsenic on behaviour of enzymes of sugar metabolism in germinating rice seeds. Acta Physiol. Plant. 27: 341-347. doi: 10.1007/s11738-005-0010-x.

Larsen, E.H., L. Moseholm and M.M. Nielsen. 1992. Atmospheric deposition of trace elements around point sources and human health risk assessment uptake of arsenic and chromium by vegetables grown near a wood preservation factory. Sci. Total Environ. $\quad$ 126(3): 263-275.

Mishra, S., A. Jha and R. Dubey. 2011. Arsenite treatment induces oxidative stress, upregulates antioxidant system, and causes phytochelatin synthesis in rice seedlings. Protoplasma. 248: 565-577. doi: 10.1007/s00709-010-0210-0.

Rahman, M.S., M.A. Hossain, M.J.U. Sarker and M.A. Bakr. 2012. Adoption and profitability of BARI lentil varieties in some selected areas of Bangladesh. Bangladesh J. Agril. Res. 37(4): 593-606. 
Shankar, S. and U. Shanker. 2014. Arsenic contamination of groundwater: a review of sources, prevalence, health risks, and strategies for mitigation. Sci. World J. 2014: 304524. https://doi.org/10.1155/2014/304524.

Smith, E., J. Smith, L. Smith, T. Biswas, R. Correll and R. Naidu. 2003. Arsenic in Australian environment: an overview. J. Environ. Sci. Health Part A Toxic/Hazard Subst. Environ. Eng. 38: 223-239.

Smith, E., R. Naidu and A.M. Alston. 1998. Arsenic in the soil environment: A review. Adv. Agron. 64: 149-195.

Stoeva, N., M. Berova and Z. Zlatev. 2003. Physiological response of maize to arsenic contamination. Biol. Plant. 47: 449-452. doi: 10.1023/b:biop.0000023893.12939.48.

Zheng, M.Z., C. Cai, Y. Hu, G.X. Sun, P.N. Williams and H.J. Cui. 2011. Spatial distribution of arsenic and temporal variation of its concentration in rice. New Phytol. 189: 200-209. doi: 10.1111/j.14698137.2010.03456.x.

Zhu, Y.G., P.N. Williams and A.A. Meharg. 2008. Exposure to inorganic arsenic from rice: a global health issue? Environ. Pollut. 154: 169-171. doi: 10.1016/j.envpol.2008.03.015. 